\section{Cyclostome Carbonic Anhydrase. Purification and Some Properties of the Enzyme from Erythrocytes of Lamprey*}

\section{LILIANE BERGLUND, UNO CARLSSON ** and BJÖRN KJELLSTRÖM}

IFM/Department of Chemistry, Linköping
University, S-581 83 Linköping, Sweden

Since carbonic anhydrase is widely distributed in nature ${ }^{1}$ comparisons of the enzyme from different species can give valuable information regarding various evolutionary aspects. The mammalian erythrocyte carbonic anhydrases have approximately the same molecular weights, about $29000-$ 30000 . This is also the case for the studied submammalian erythrocyte carbonic anhydrases, ${ }^{2}$ except the elasmobranch carbonic anhydrases which have molecular weights of $36000-39000 .^{3}$

In order to see whether the heavier elasmobranch carbonic anhydrase is the archtypal vertebrate enzyme, as has been earlier suggested, ${ }^{2}$ we have recently investigated the erythrocyte carbonic anhydrase from hagfish (Myxine glutinosa), ${ }^{4}$ belonging to the cyclostomes, which are considered to be the most primitive vertebrates. Since the molecular weight of the hagfish enzyme was determined to 29000 , we wanted to get further evidence for the idea that a carbonic anhydrase with a molecular weight of about 29000 rather than a heavier one is the ancestral vertebrate enzyme. Therefore we have purified the erythrocyte carbonic anhydrase from lamprey (Lampetra fluviatilis), which also belongs to the cyclostomes.

Experimental. Blood was obtained from a vein of freshly caught lamprey by using a syringe with

\footnotetext{
* Communication at the Meeting of the Swedish Biochemical Society in Stockholm, 29th November, 1979.

** To whom correspondence should be addressed.
}

heparin-treated needles. The erythrocytes were isolated by centrifugation $\left(2000 \mathrm{~g}, 20 \mathrm{~min}, 5^{\circ} \mathrm{C}\right)$ and washed by an equal volume of cold $0.9 \%$ $\mathrm{NaCl}$. Hemolysis was achieved by addition of a 5-fold volume excess of distilled water. The hemolysate was dialyzed over night against $0.01 \mathrm{M}$ Tris$\mathrm{H}_{2} \mathrm{SO}_{4}, \mathrm{pH} 7.0$.

The purification was made on a $p$-aminobenzenesulfonamide Sepharose column ${ }^{5}(2.0 \times 20 \mathrm{~cm}$, flow rate $15 \mathrm{ml} / \mathrm{h}, 5^{\circ} \mathrm{C}$ ) equilibrated with $0.1 \mathrm{M}$ Tris $\mathrm{H}_{2} \mathrm{SO}_{4}$, $\mathrm{pH}$ 7.0. Adsorbed hemoglobin to the gel was washed away by the above buffer containing $0.4 \mathrm{M} \mathrm{Na}_{2} \mathrm{SO}_{4}$ and elution was performed by $0.1 \mathrm{M}$ Tris $-\mathrm{H}_{2} \mathrm{SO}_{4}, \mathrm{pH} 7.0$ containing $0.6 \mathrm{M}$ NaI. The carbonic anhydrase fractions were desalted on a Sephadex G- 25 column $(1 \mathrm{~cm} \times 8 \mathrm{~cm})$. The $\mathrm{CO}_{2}$ hydration activity was measured according to Rickli et $a .^{6}$ and the activity units are defined according to: Activity units $=10\left(t_{\mathrm{b}}-t_{\mathrm{c}}\right) / t_{\mathrm{c}}$, where $t_{\mathrm{b}}$ and $t_{\mathrm{c}}$ are the times for obtaining the color change of the indicator in uncatalyzed and catalyzed reactions, respectively. The homogeneity of the preparation was analysed by polyacrylamide gel electrophoresis ${ }^{7}(7.5 \%$ acrylamide, $0.095 \mathrm{M}$ Tris-glycine, $\mathrm{pH} 9.5$ ). Isoelectric focusing was performed in an LKB Model 8101 focusing column ${ }^{8}$ in a pH gradient of 3.5 to 10 . Molecular weight analysis was carried out by gel filtration on a Sephadex G-100 column $(2.1 \mathrm{~cm} \times 110$ $\mathrm{cm}, 0.1 \mathrm{M} \mathrm{KCl}$ in $0.05 \mathrm{M}$ Tris $-\mathrm{HCl}, \mathrm{pH} 7.5$ ). Using high molecular weight blue Dextran, the void volume, $V_{v}$, was determined to be $138 \mathrm{ml}$. The calibration proteins were eluted at the following volumes: Bovine serum albumin $\left(M_{\mathrm{w}}=67000^{9}\right)$, $1.36 V_{\mathrm{v}}$; human carbonic anhydrase B $\left(M_{\mathrm{w}}=\right.$ $\left.28900^{10}\right), 1.88 V_{\mathrm{v}}$; and horse heart cytochrome $c$ $\left(M_{\mathrm{w}}=12400^{11}\right), 2.44 V_{\mathrm{v}}$.

Results and discussion. A summary of the yield enzyme activity during the purification of lamprey carbonic anhydrase is shown in Table 1 . From the affinity chromatography $\mathrm{CO}_{2}$ hydration activity was only detected in a single peak. Analysis by polyacrylamide gel electrophoresis of the pooled fractions containing enzymic activity revealed only one band, suggesting high purity of the preparation. Isoelectric focusing of the hemolysate also

Table 1. Purification of lamprey erythrocyte carbonic anhydrase. The data in this table are from one preparation from $13 \mathrm{ml}$ of hemolysate.

\begin{tabular}{llcc}
\hline Purification step & $\begin{array}{l}\text { Total activity/ } \\
\text { units } \times 10^{-4}\end{array}$ & $\begin{array}{l}\text { Specific activity/ } \\
\text { units } / \mathrm{A}_{280} \mathrm{~nm} \times 10^{-3}\end{array}$ & Yield $/ \%$ \\
\hline 1. Hemolysis & 1.21 & 0.019 & 100 \\
2. Dialysis & 1.07 & 0.016 & 88 \\
3. Affinity chromatography & $0.38^{\mathrm{a}}$ & $23.5^{\mathrm{a}}$ & 31 \\
\hline
\end{tabular}

a After desalting of the enzyme. 
showed only one active component, indicating that there is only one erythrocyte form of the lamprey carbonic anhydrase. The $\mathrm{p} I$ of the lamprey carbonic anhydrase was determined to be 5.2. After desalting of the enzyme fractions by gel filtration the enzyme was concentrated by lyophilization. By these procedures no inactivation of the enzyme was noted. If alternatively dialysis overnight was used to remove $\mathrm{NaI}$, a $50 \%$ loss of activity occurred. Concentration of the enzyme by vacuum dialysis also resulted in inactivation. In the purification of elasmobranch ${ }^{3}$ and hagfish ${ }^{4}$ carbonic anhydrases problems with inactivation of the enzyme during various dialysis steps were also noticed. Addition $\mathrm{Zn}$ (II) lead to reactivation of the inactivated hagfish carbonic anhydrase, ${ }^{4}$ but had no effect on the lamprey enzyme. Two gel filtrations of lamprey carbonic anhydrase resulted in elution after 1.87 and 1.88 void volumes, corresponding to the molecular weights of 29200 and 28900 , respectively. This molecular weight is in agreement with that of the hagfish carbonic anhydrase which supports our earlier suggestion that the ancestral vertebrate carbonic anhydrase had a molecular weight of approximately $29000 .^{4}$

Acknowledgement. We wish to thank the staff of Statens Fiskeristyrelse, Älvkarleby who provided us with lamprey.

1. Lindskog, S., Henderson, L. E., Kannan, K. K., Liljas, A., Nyman, P. O. and Strandberg, B. In Boyer, P. D., Ed., The Enzymes, Academic, New York 1971, Vol. 5, p. 587.

2. Bundy, H. F. Comp. Biochem. Physiol. B 57 (1977) 1.

3. Maynard, J. R. and Coleman, J. E. J. Biol. Chem. 246 (1971) 4455.

4. Carlsson, U., Kjellström, B. and Antonsson, B. Biochim. Biophys. Acta. In press.

5. Falkbring, S. O., Goethe, P. O., Nyman, P. O., Sundberg, L. and Porath, J. FEBS Lett. 24 (1972) 229.

6. Rickli, E. E., Ghazanfar, S. A. S., Gibbons, B. H. and Edsall, J. T. J. Biol. Chem. 239 (1964) 1065.

7. Smith, I. Chromatographic and Electrophoretic Techniques, 2nd Ed., Heinemann, London 1968, Vol. 2, p. 365.

8. Vesterberg, O. Methods Enzymol. 22 (1971) 389.

9. Castellino, F. J. and Barker, R. Biochemistry 7 (1968) 2207.

10. Andersson, B., Nyman, P. O. and Strid, L. Biochem. Biophys. Res. Commun. 48 (1972) 670.

11. Margoliash, E. J. Biol. Chem. 237 (1962) 2161.

Received November 19, 1979. 